\title{
DIGITALISATION OF PROFESSIONAL (VOCATIONAL) AND PRE-HIGH TERTIARY EDUCATION OF UKRAINE: PROBLEMS AND PROSPECTS
}

\author{
Mykola-Oleg Yershov, \\ Pedagogic department PhD student, Zhytomyr Ivan Franko State University \\ https://orcid.org/0000-0002-6839-622X \\ e-mail: my.yershov@gmail.com
}

\begin{abstract}
The national professional (vocational) and pre-high tertiary education are represented based on the analisys national legislation, the materials of Ukrainian and foreign mass-media, scientific articles on reforming education system issues, statistic data of Ministry of Education and Science of Ukraine, State Statistics Service of Ukraine, State Employment Service, the Internet-sources (HeadHanter, UNESCO Database, Approved Event (UFI), Eurostat Educational Statistics), VET schools and colleges web-sites, analytical materials the Institute of vocational education of the National academy of educational sciences of Ukraine (NAES), Institute of information technologies and learning tools of NAES of Ukraine.

Common problems of professional (vocational) and pre-high tertiary education digitalisationare the following: education development lagging (content, training forms and methods, technical equipment) in comparison with digital technologies development pace: outdated occupations; education program content and labour market requirements disbalance; conservative training methods and forms for future specialists training and the teaching staff upskilling, VET schools outdated material and technical basis; low digital competence level of most VET schools managers and teaching employees; poor communication of business, IT companies and education establishments. The professional (vocational) and pre-high tertiary education digitalisation prospects are identified in the context of digital society building and digital economy development: public-private partnership strengthening; dual form of education introduction; distance and mixed learning (blended learning) organization; inclusive education introduction; competence-based approach in the educational process; scientific and educational on-line platforms creation; individual education pathways building at educational institutions for employment in "digital workplaces"; the introduction of new forms and methods for educators digital competence improving the (digital workshops, barcamps, virtual laboratories).
\end{abstract}

Keywords: IT education, education digitalisation, digital competence, digital culture, professional (vocational) and pre-high tertiary education.

Introduction. In the early 2000 all around the world the share of the traditional economy is decreasing and, at the same time, the digital one is rapidly increasing. The analytical materials of the World Economic Forum in Davos (2019) identified a list of the most promising digital technologies, including mobile, cloud, biometric, blockchain, virtualization, augmented reality, additive (3D-printing), identification, digital intelligence. Among the priority issues of the world community is the search for new tarining forms and methods to provide vocational education and training
(VET) schools leavers with skills for life and work under the conditions of Industry 4.0.

The forum noted that 10 trillion dollars are being spent to train 1.5 billion children in the world At the same time, it was stressed that mostly these investments are for the "curricula and subjects not been changed for 150 years" (Kornienko, 2019). This problem is completely crucial for VET and pre-high tertiary education (pHTE) in Ukraine when the digital economy is a new and unusual development paradigm.

The first step towards the domestic digital economy development was made by the Ordinance of the 
Cabinet of Ministers of Ukraine in 2018 "On approval the concept for developing the digital economy and society of Ukraine 2018-2020 and adopting the plan of implementation activities" (Ukrainian Legislation, 2018). The Concept focuses on developing the digital competences for all Ukrainian citizens, implementing the concepts on digital jobs, real sector of economy digitization and forming the thorough national policy for degitalisation the education sector. Therefore, the analysis of the national VET main problems and perspectives in the context of digital society and economy development and the enderpinned need to solve the government's priority tasks on education process digitalization is an urgent problem for modern professional and pre-high tertiary education.

Materials. By and large the attention of modern researchers is focused on the problems of general secondary education informatization in Ukraine, ICT use in school education, theoretical and methodological principles for computer science teachers training etc. At the same time, some aspects of national professional (vocational) education $(\mathrm{P}(\mathrm{V}) \mathrm{E})$ and $\mathrm{pHTE}$ systems digitalization are represented in papers by O. V. Baseliuk, V. Yu. Bykov, O. D. Humenniy, A. M. Gurzhiy, A. G. Kononenko, N. V. Morse, L. M. Petrenko, V. O. Radkevych, O. M. Spirin and others. Among the recent studies, the following works should be noted: O. V. Baseliuk (2019, p. 5), where VET digitalization is represented as a global socionatural process; A. G. Kononenko (2016, pp. 61-64) devoted to various aspects of informational and educational environment creation in VET schools; O. D. Humenniy and V. O. Radkevych (2016, pp. 1119) on studying SMART-complexes for educational subjects in VET schools and the information culture of managers (Humenniy, 2013, pp. 84-89), M.-O. Ershov (2018, pp. 79) outlining the role of Ukrainian IT education in the global market for information products and services. At the same time, the issue of continuity coverage in the domestic IT education development and generalizing main trends on modern VET and pHTE digitalization are still crucial.

Therefore, the research aim is to identify and analyse main problems and perspectives of digitalization the modern professional (vocational) and pre-high tertiary education in Ukraine.

To achieve the stated goal, the methods of analysis, systematization and synthesis of the elaborated sources are used, among them: natioanl legislative documents, materials of Ukrainian and foreign mass media, scientific publications on education system reforming in Ukraine, statistics of the Ministry of Education and Science of Ukraine, State Statistics Service of Ukraine, State Employment Service, the Internet-sources (HeadHanter, UNESCO Database, Approved Event (UFI), Eurostat Educational Statistics), analytical materials and reports of the Institute of vocational education of the National academy of educational sciences of Ukraine (NAES), Institute of information technologies and learning tools of NAES of Ukraine, etc.

Results and discussions. "The Concept on development the digital economy and society of Ukraine 2018-2020" is focused on important economic and social trends that can be taken into account in the process of national VET and pHTE systems reforming. Among them there are the digital competencies development for all citizens of Ukraine, the real sector of economy digitalization and the concept on digital jobs impelmentation (Ukrainian Legislation, 2018).

Despite the outlined tasks prolongation on the long run, the Concept authors deliberately limited the validity of the document for a three-year term (20182021) (Dubrovik-Rokhova, 2018). According to the Moore Act (Moore, Gordon E., Cramming more components on integrated circuits, Electronics, Vol. 32, No. 8, April 19, 1965), the speed and development of digital technology should double each year. So, three years study at the educational institution for the digital world means six. Even taking into account the fact that the Moore Act was limited in time (DLOG MIT, 2017), nowadays it is increasingly being discussed changing the high-speed paradigm of digital technology development, thanks to its intensive logistics development in various spheres of activity. In particular, engineers and businesses made operating plans and computer vendors could predict the vanishing and forthcoming generations of machines.

At the World Economic Forum in Davos (2019), the problem of the education development lag comparative to digital technologies development movement was called the global challenge of our age. Forum participants admitted that mostly educational investment was directed at curricula and subjects not been undergone the significant changes for long time. The post-Soviet VET system turned out to be too cumbersome and awkward to meet the ever-increasing economy and society needs of a changing digital era. Already traditional VET system critical gap with society and economy demands, those being digitalised much faster, is explained by digital technologies rapid development pace. At the same time, there are some other reasons.

For example, VET digitalization problems are also related to the teachers' digital competence level and the outdated material and technical base of a large number of VET schools. In lots of VET schools managers and educators still prefer a printed book and chalk, rather than electronic educational resources, SMART complexes, distance learning forms, virtual labs, etc. This is confirmed by the results of an experimental study of VET schools managers' and 
pedagogical staff's readiness to develop and use SMART complexes for skilled worker staining. The experiment was conducted by IVET of NAES of Ukraine in 2018 (Prihody, 2018). As a part of the study the hypothesis on teaching employees' readiness to develop and use SMART-complexes is capable to be developed while increasing their SMART-technologies awareness level was put forward. Therefore, the attention was focused on the following levels identification. It was found that only one third of the interviewed VET managers has a high level of SMART-technologies awareness. In addition, it was found that $79 \%$ of interviewed VET managers use the uncomputerised information sources for their work, and only $21 \%$ the computerized ones.

It is also established that the overwhelming majority of managers can not conduct research using virtual reality systems, use arrays of information stored in it, and construct managerial situations models of information-analytical and psychology-pedagogical nature. It is found that $52 \%$ of teachers those asked of general and specialist disciplines do not understand how the subject SMART complex can contribute to improving teaching quality. Moreover, for the experienced educators (of more than twenty years) this tendency is more vivid. This can be explained by the fact that this category of teachers did not receive proper informational education in his/her time and during his/ her next professional activity he/she himself/herself was not able to master digital skills at sufficient level for of modern vocational training efficient organization. It is obvious that such low digital-skills of VET schools managerial and pedagogical staff are seriously hampering $\mathrm{P}(\mathrm{V}) \mathrm{E}$ digitalization processes. Thus, the problem of increasing the digital competence level (a set of knowledge and skills necessary for using ICT and digital media in pedagogical activities) and digital culture (value system, digital competence, ethical behaviour in the field of digital relations, critical thinking and creativity) is outlined (Baseliuk, 2018, pp. 83-84). The traditional system of teachers advanced evelopment cannot out-do this problem independently. Obviously, it needs to be solved with employers, civic organizations, and IT companies. In particular, BarCamps - informal democratic open interactive meetings of educators, researchers, IT specialists, business representatives, non-governmental organizations, and government officials - have proved to be an effective form of teachers digital culture and competence increasing. These are conferences of open discussions, trainings, presentations form where the informal atmosphere motivates participants for selfeducation and self-development.

The low pace of VET digitalisation is also attributable to very weak links of VET and business.
It is known, for example, that in the second half of XIX century the attention of businessmen to their children's education level became steadily increasing. If in the 1860's their educational level reached a commercial school or a real college, then since the 1890 's it went up to a prestigious university or a higher technical institution. At the end of XIX century for the entrepreneurial class, education became not only the element of prestige, but also a reason for financial security of the merchant dynasties (Yershova, 2015, p. 117). That was explained by the fact that the head of the family inherited not only his acquired capital but also a special economic way of thinking, where the education of workers was a condition for creating a stable social environment for the expansion of entrepreneurial activity. The intensively growing demand of the economy in educated specialists helped entrepreneurs to realize the need for modern professional education not only for their workers, but also for raising the general educational level of the population. That motivated the commercial and industrial elite to establish and maintain modern educational institutions - commercial, technical, and artisan (Yershova, 2018, p. 158).

Unfortunately, nowadays business structures are only beginning to show an active interest in taking part in completing the order for workers training and updating VET content in accordance with digital economy requirements. This is reflected in the Concept of development the digital economy and society of Ukraine 2018-2020, where the "human capital, ie knowledge, talents, skills, experience, people's intelligence" was recognized as the driving force (Ukrainian Legislation, 2018, p. 5). At the same time, the Concept in the part "Education", first of all, emphasizes the conditions of improvement the general secondary education digitalization without direct focus on the corresponding problems of VET and pHTE. However, the text of the document adresses not only to pupils but also to students and can serve as evidence of the Concept provisions extension on VET and pHTE also.

In particular, the Concept refers to the need to digitize the agricultural sector and the competitiveness of domestic farmers as well. That is, a new stage in the agrosphere development will require the ability of modern specialists to use geoinformation systems, onboard computers, smart equipment, to implement innovative ways of cultivating plants and soils, fertilizing and chemical melioration, plant protection products, servicing soil scanners, vertical greenhouses and drones, helicopters-sprayers, etc. According to well-known McKinsey Global Institute research, the leader in replacing manual labour will be the agriculture sector where the largest number of workers 
is emploed (Today, 2017). Thus, there is a need to prepare VET and pHTE graduates for "digital agriculture" introduction, called "precise agriculture" in mass-media. In agro professions top of near future, those are already in the scope of interests of leading agrocompanies of Ukraine, there is an engineer of precision farming systems, a digital agronomist, an agri data analyst, an innovator. These professions those can be successfully mastered by pHTE graduates in terms of quality digitalisation.

For example, vacancies of precision farming engineers in the media are called "vacancy of dreams" for today's young mechanics, machine operators, and service center engineers (Approved Event (UFI), 2018). These specialists are expected to become "universal soldiers" of the agrarian sector, able to cope with microprocessors, innovative GIS-systems and monitoring systems. It is also forecasted that in several years the agronomists' digital-skills to operate drones, plan agro-operations with the help of a single farm platform (farm-management) and digital maps (farmmanagement) - will form the basis for hard-skills formation and successful professional career building.

To form those skills, only classroom work in educational institutions is obviously not enough. It requires permanent practice and self-education. If modern educational institutions can not provide that, their bankruptcy will only be a matter of time. International exhibitions of agricultural machinery and equipment, taking place in Kyiv, prove that by demonstrating rapid agriculture sector digitization. In addition, the Annual Young Specialists Days, called "Career fair" (UFI), 2018), also confirm the fact that at the following occupations are already vacancies in many agro-companies of Ukraine (Eridon, LLC "Agrobudnevny alliance" Astra "AMACO Ukraine LLC", "Agrosem Ltd.", "Agrotek" Ltd., "Ukravtozapchastna" LLC, TM Khlibodar, Timac Agro Ukraine LLC, Cygnet Agrocompany, TERRA FUD Group, LLC "Food DEVELOPMENT", LLC "Bison" -Import ", Ltd. AVD YU avd-ua.com, PrAT Volodymyr-Volynsky poultry farm" Epicurus ", Kernel, UKRAVIT Group of Companies).

Rapid digitization tendency in agro-sector will increase the interest of modern agribusiness in using digital technologies not only in the field, but also in the household and workers' homes. In essence, at present the agricultural sector digitization is the only real way to stop the disruption to rural community, reducing the rural population incomes and their migration to cities. Hence, agriculture sector digitization is a dialectical chance to regain the prestige of agroprofessions that already occurred in Ukrainian villages in the 50 s of the last century, when a tractor driver and an agronomist were the most prestigious professions in society.
The same thing happens in industry sector oriented on Industry-4.0. A serious challenge for modern VET and pHTE systems has become a powerful wave of advanced technologies (cloud, mobile, paperless, unmanned, additive, biometric, quantum, through, block, supercomputer, identification, open source), as well as the Internet of things, "big data, "predictive analytics", fuzzy calculations, robotics, artificial intelligence, etc. (Yanenkova, 2017, pp. 182-183). No doubts, there is a need to bring together digital industry and industry representatives to develop new products and services, create "road maps" of digital transformations for the search, digitalization initiatives development and implementation in the industry. It also requires skilled workers and professionals of a new quality capable to work with Industry 4.0 technologies. That is, the modern VET schools and colleges have to train prepare their graduates to perform their professional functions in terms of "digital workplace".

In the draft of the Strategy of Ukraine for the industrial complex development up to 2025, the shortage of skilled workforce for industry needs was recognized as the second of the eight key problems of domestic industry development (Ministry of Economic Development and Trade of Ukraine, 2018). The situation in Ukraine with an insufficient number of skilled workforces is alleged to be aggravated. For example, at the end of 2017, the demand of employers for skilled workers with the tool was almost $24 \%$ of the total economic number of vacancies. The demand of employers for technical staff, operators of technological equipment and machines doubled. The situation deterioration is due to the mass outflow of skilled workforce abroad. According to Eurostat (2016), the number of visas issued to the Ukrainians for residence in EU countries more than doubled. Moreover, $75 \%$ of the permits received were related to employment. Since 2009, the number of the Ukrainians who went abroad to study abroad has increased by $129 \%$ as well. According to IVET (2017), the survey of VET students regarding the choice of the country for their further professional career development also suggest that $43 \%$ of the respondents (sample - 1680 students) see that outside Ukraine, and $24 \%$ were not determined on this issue (Yershova, 2018, pp. 166).

The unsatisfactory position of modern vocational education is conditioned by its outdated material and technical base, low wages of teachers and masters of industrial training, low level of their readiness to use ICT in educational process, training methods and forms disbalance with LM and economy needs, low communication level between industry, education and IT companies. To overcome the educational crisis, the mere declaration of the country's course on the 
digitization of the economy and society is obviously not enough. The leading economists of Ukraine emphasize that any state will be able to maximize the return on the digitization of its economy only if the money is constantly invested in the education system (Yanenkova, 2017, p. 179).

Thus, one of the important directions of the Strategy of Ukraine for the industrial complex development up to 2025 implementation is to provide professional staff training in accordance with industry needs. To this end, it is proposed: to popularize and distribute the system of dual education; practice work-based learning (WBL); support training centers setting and development at industrial enterprises; organize seminars and training courses to build new staffing competencies in industry with a view to introducing digital technologies and ensuring effective communication between industry and education; to modernize professional standards of industrial specialties; systematically supplement the list of new professions, determined by digital competencies, and add them to the State Classification of Professions (Ministry of Economic Development and Trade of Ukraine, 2018). The offered measures analisys of the Strategy draft confirms the readiness of the state to support their implementation not only within formal education, but also directly in production. Therefore, if the system of formal vocational education is not quickly upgraded taking into account all modern challenges, then there are high risks for the loss educational services monopoly.

The course of Ukraine to create a digital economy puts the society and the state face-to-face with the problem of choosing the priority of technology development or use. Obviously, business, manufacturing, state, and citizens are the best consumers of the technologies designed and adapted to the needs of the mass consumer of digital technology. On the other hand, it is logical that fundamental and applied sciences, entrepreneurs-innovators, startup communities, in the first place, should focus on new technologies and products creation. However, Ukraine, where IT specialists, as the media wrote, "has already digitized the half of the world (Dubrovik-Rochova, 2018), has only now officially embarked on the digital economy development and recognized the need for training specialists capable to create their own innovative technologies. In light of this, the digital education system is intended to prepare not only a mass digital technologies consumer but also a creative person capable to produce new ideas and products under certain conditions.
Hence - there is a problem of appropriate methods selection, training means and forms for a professional innovator training. It requires: distance education development; broadband access to the Internet for trainees and students; digital platforms creation with interactive and multimedia content support for the general access of institutions and educational entities, tools for automating main working processes of an educational institution; introduction of innovative computer, multimedia, computer-based learning tools, high-tech equipment for creating a digital educational environment (mixed learning classes, multimedia and inclusive classes, research STEM centers, virtual laboratories); the study of computer science with emphasis on teamwork and creativity; games-based learning to develop critical thinking.

The ignoting by formal education system managers these obvious tendencies and needs will only lead to the qualified personnel's attention switching to the system of informal and non-formational education. Its perspectives are quite clearly formulated in many government documents.

Conclusions. The general problems of national VET and pHTE digitalization were identified and characterized, namely: the development of education from the pace of development of digital technologies; curricula content and LM needs disbalance; low communication level of business, IT companies and educational institutions; obsolete specialties, according to which VET schools train specialists; low level of VET schools managers' and teaching staff digital competence; conservative training methods and forms for future specialists and teachers upskilling; outdated Vet schools material and technical base.

The prospects of digitalization VET and pHTE in the context of digital society and economy development are defined: public-private partnership strengthening; dual form of education introduction; distance and mixed learning (blended learning) organization; inclusive education introduction; competence-based approach in the educational process; scientific and educational on-line platforms creation; individual education pathways building at educational institutions for employment in "digital workplaces"; the introduction of new forms and methods for educators digital competence improving the (digital workshops, barcamps, virtual laboratories).

The prospective areas for further researches are the study of informal and informational IT education development peculiarities in Ukraine. 


\section{List of references}

Базелюк, О., 2018. Зміст і структура цифрової культури педагогічних працівників закладів професійної освіти. Науковий вісник Інституту професійно-технічної освіти НАПН Украӥни. Професійна педагогіка, 16, с. 81-87. DOI: http://doi.org/10.32835/2223-5752.2018.16.81-87.

Базелюк, О.В., 2019. Цифровізація професійної освіти як глобальний соціоприродній процес. В: Інформаційно-иифровий освітній простір Украӥни: трансформаиійні процеси і перспективи розвитку. Програма методологічного семінару (Київ, Україна, 4 Квітень 2019). К.: Інститут інформаційних технологій і засобів навчання НАПН України.

Верховна Рада України. Законодавство України, 2018. Концепція розвитку цифрової економіки та суспільства Украӥни на 2018-2020 роки. Розпорядження Кабінету міністрів України від 17 січня 2018 року № 67-p. [online] (Останнє оновлення 1 Січень 2018) Доступно: <https://zakon.rada.gov.ua/laws/show/67-2018-\%D1\%80> (Дата 3вернення 17 Квітень 2019).

Гуменний, О.Д., 2013. Інформаційна культура керівників ПТНЗ у психолого-педагогічних дослідженнях. Сучасні інформачійні технології та інновачійні методики навчання у підготовці фахівців: теорія, досвід, проблеми, 35, с. 84-89.

Гуменний, О.Д. та Радкевич, В.О., 2016. SMART-комплекси навчальних дисциплін для професійно-технічних навчальних закладів. Теорія і методика професійної освіти, 3 (11), с. 11-19.

Дубровик-Рохова, А., 2018. Діджиталізація - це лише початок. День, [online] 65-66. Доступно: https://day.kyiv.ua/ uk/article/ekonomika/didzhytalizaciya-ce-lyshe-pochatok [Дата звернення 2 Травень 2019].

Єршова, Л., 2018. Від купця - до підприємця: трансформація цінностей української економічної еліти у ХІХ на початку ХX століття. Науковий вісник Інституту професійно-технічної освіти НАПН Украӥни. Професійна педагогіка, 15, с. 154-161.

Єршова, Л., 2015. Трансформачія виховного ідеалу в Украӥні (ХІХ-початок ХХ століття): Київський, Одеський, Харківський навчальні округи. Житомир: Видавець Євенок О.О., 2015.

Єршова, Л., 2018. Трансформація системи цінностей учнівської і студентської молоді в контексті реформування вітчизняної професійної освіти. Науковий вісник Інституту професійно-технічної освіти НАПН України. Професійна педагогіка, 16, с. 162-168. DOI: http://doi.org/10.32835/2223-5752.2018.16.162-168.

Єршов, М.-О., 2018. Роль української ІТ-освіти на світовому ринку інформаційних товарів і послуг Науковий вісник Інституту професійно-технічної освіти НАПН України. Професійна педагогіка, 16, c. 74-81. DOI: http:// doi.org/10.32835/2223-5752.2018.16.74-81.

Кононенко, А.Г., 2016. Інформаційно-освітнє середовище як сучасна складова фахової підготовки майбутніх робітників-слюсарів з ремонту автомобілів. В: Освітні інновації у вищих навчальних закладах: проблеми використання інформаційно-комунікаційних технологій: зб. наук.пр. Матеріали науково-практичної конференції (Ізмаїл, Україна, 14 травня 2016 ), с. 61-64.

Корнієнко, Я., 2019. Давос-2019: головні меседжі Всесвітнього економічного форуму. Экономическая правда, [online] Доступно: <https://www.epravda.com.ua/rus/publications/2019/01/27/644694/> [Дата звернення 17 Квітень 2019].

Міністерство економічного розвитку і торгівлі України. Офіційний ве-сайт, 2018. Проект розпорядження кабінету Міністрів України "Про схвалення стратегії розвитку промислового комплексу Украӥни на період до 2025 року". [onlaine] (Останнє оновлення 17 Квітень 2018) Доступно: <http://www.me.gov.ua/Documents/Detail?lang=ukUA\&id=10ef5b65-0209-4aa1-a724-49fd0877d8d6\&title=ProektRozporiadzhenniaKabinetuMinistrivUkrainipro SkhvalenniaStrategiiRozvitkuPromislovogoKompleksuUkrainiNaPeriodDo2025-Roku> (Дата звернення 2 Травень 2019.)

Пригодій, М.А., 2018. Державний реєстраційний номер 0118U003223. Методичні основи розроблення SMARTкомплексів для підготовки кваліфікованих робітників аграрної, будівельної і машинобудівної галузей. Лабораторія електронних навчальних ресурсів, Інститут професійно-технічної освіти НАПН України, переглянуто 22 Квітень 2019.

Сегодня, 2017. Ton-10 новых профессий в украинской промышленности. [online] (Останнє оновлення 29 Вересень 2017) Доступно: <https://www.segodnya.ua/economics/business/rabota-v-vek-robotov-v-ukrainskoypromyshlennosti-poyavlyayutsya-novye-professii-1059555.html> (Дата звернення 2 Травень 2019).

Яненкова, І.Г., 2017. Цифрова трансформація промисловості України: ключові акценти. Економіка та управління національним господарством, 4, с. 179-184.

Approved Event (UFI), 2018. Топ агро-професій 2018 року. [online] (Останнє оновлення 1 Листопад 2018) Доступно: <http://interagro.in.ua/ru/6318-top-agro-profesij-2018-roku> (Дата звернення 2 Травень 2019).

DLOG MIT, 2017. The End of Moore's Law. [onlaine] Available at: <http://rodneybrooks.com/the-end-of-mooreslaw/> [Accessed 25 Aprile 2019].

\section{Translated \& Transliterated}

Bazeliuk, O., 2018. Zmist i struktura tsyfrovoi kultury pedahohichnykh pratsivnykiv zakladiv profesiinoi osvity [Content and structure of digital culture of VET institutions' teachers]. Naukovyi visnyk Instytutu profesiino-tekhnichnoi osvity NAPS Ukrainy. Profesiina pedahohika [Scientific herald of the Institute of vocational education and training of NAES of Ukraine. Professional Pedagogy], 16, s. 81-87. DOI: http://doi.org/10.32835/2223-5752.2018.16.81-87, [in Ukrainian].

Bazeliuk, O.V., 2019. Tsyfrovizatsiia profesiinoi osvity yak hlobalnyi sotsiopryrodnii protses [Professional education transformation as a glibal socio-natural protest]. V: Informatsiino-tsyfrovyi osvitnii prostir Ukrainy: transformatsiini protsesy i perspektyvy rozvytku. Prohrama metodolohichnoho seminaru [Information-digital education environment of 
Ukraine: transformation protests and development prospects] (Kyiv, Ukraine, 4 Kviten 2019). K.: Instytut informatsiinykh tekhnolohii i zasobiv navchannia NAES Ukrainy, [in Ukrainian].

Verkhovna Rada Ukrainy. Zakonodavstvo Ukrainy [Verkhovna Rada of Ukraine. Legislation of Ukraine], 2018. Kontseptsiia rozvytku tsyfrovoi ekonomiky ta suspilstva Ukrainy na 2018-2020 roky. Rozporiadzhennia Kabinetu ministriv Ukrainy vid 17 sichnia 2018 roku № 67-r. [The Concept on development the digital economy and society of Ukraine 20182020. The ordinance of the Cabinet of Ministers of Ukraine N67-r dated 17.01.2018] [online] (Ostannie onovlennia 1 Sichen 2018) Dostupno: < https://zakon.rada.gov.ua/laws/show/67-2018-\%D1\%80> (Data zvernennia 17 Kviten 2019), [in Ukrainian].

Humennyi, O.D., 2013. Informatsiina kultura kerivnykiv PTNZ u psykholoho-pedahohichnykh doslidzhenniakh [VET schools managers' information culture in psycho-pedagogic researches]. Suchasni informatsiini tekhnolohii ta innovatsiini metodyky navchannia u pidhotovtsi fakhivtsiv: teoriia, dosvid, problem [Modern informational technologies and innovations of training methodics for specialists training: theory, experience, prblem], 35, s. 84-89, [in Ukrainian].

Humennyi, O.D. ta Radkevych V.O., 2016. SMART-kompleksy navchalnykh dystsyplin dlia profesiino-tekhnichnykh navchalnykh zakladiv [Subjects SMART complexes for VET schools]. Teoriia i metodyka profesiinoi osvity [Professional education theory and methodology], 3 (11), s. 11-19, [in Ukrainian].

Dubrovyk-Rokhova, A., 2018. Didzhytalizatsiia - tse lyshe pochatok [Digitalisation is only the begining]. V: Den [Day], [online] 65-66. Dostupno: https://day.kyiv.ua/uk/article/ekonomika/didzhytalizaciya-ce-lyshe-pochatok [Data zvernennia 2 Traven 2019], [in Ukrainian].

Yershova, L., 2018. Vid kuptsia - do pidpryiemtsia: transformatsiia tsinnostei ukrainskoi ekonomichnoi elity u XIX - na pochatku XX stolittia [From a tradesman to an entrepreneur: the Ukrainian business leaders' values transformation in XIX and early XX centuries]. Naukovyi visnyk Instytutu profesiino-tekhnichnoi osvity NAPS Ukrainy. Profesiina pedahohika [Scientific herald of the Institute of vocational education and training of NAES of Ukraine. Professional Pedagogy], 15, s. 154-161, [in Ukrainian].

Yershova, L., 2015. Transformatsiia vykhovnoho idealu v Ukraini (XIX-pochatok XX stolittia): Kyivskyi, Odeskyi, Kharkivskyi navchalni okruhy [Educational ideal transformation in Ukraine (XIX-early XX century): Kyiv, Odessa, Kharkiv education areas]. Zhytomyr: Vydavets Yevenok O.O., [in Ukrainian].

Yershova, L., 2018. Transformatsiia systemy tsinnostei uchnivskoi i studentskoi molodi v konteksti reformuvannia vitchyznianoi profesiinoi osvity [Transformation of the students' values system in the context of domestic vocational education and training reforming]. Naukovyi visnyk Instytutu profesiino-tekhnichnoi osvity NAPS Ukrainy. Profesiina pedahohika [Scientific herald of the Institute of vocational education and training of NAES of Ukraine. Professional Pedagogy], 16, s. 162-168. DOI: http://doi.org/10.32835/2223-5752.2018.16.162-168, [in Ukrainian].

Yershov, M.-O., 2018. Rol ukrainskoi IT-osvity na svitovomu rynku informatsiinykh tovariv i posluh [The role of Ukrainian IT education in the world market of information products and services]. Naukovyi visnyk Instytutu profesiino-tekhnichnoi osvity NAPS Ukrainy. Profesiina pedahohika [Scientific herald of the Institute of vocational education and training of NAES of Ukraine. Professional Pedagogy], 16, s. 74-81. DOI: http://doi.org/10.32835/2223-5752.2018.16.74-81, [in Ukrainian].

Kononenko, A.H., 2016. Informatsiino-osvitnie seredovyshche yak suchasna skladova fakhovoi pidhotovky maibutnikh robitnykiv-sliusariv z remontu avtomobiliv [Information-education environment as a modern component of occupational training for future workers - automotive service technicians]. V: Osvitni innovatsii u vyshchykh navchalnykh zakladakh: problemy vykorystannia informatsiino-komunikatsiinykh tekhnolohii: zb. nauk.pr. Materialy naukovo-praktychnoi konferentsii [Education innovations in high education institutions: problems of using information-communication technologies] (Izmail, Ukraina 14 Traven 2016), s. 61-64, [in Ukrainian].

Korniienko, Ya., 2019. Davos-2019: holovni mesedzhi Vsesvitnoho ekonomichnoho forumu. Ekonomicheskaya pravda [The economic truth], [online] Dostupno: < https://www.epravda.com.ua/rus/publications/2019/01/27/644694/> [Data zvernennia 17 Kviten 2019], [in Ukrainian].

Ministerstvo ekonomichnoho rozvytku i torhivli Ukrainy. Ofitsiinyi ve-sait, 2018. Proekt rozporiadzhennia kabinetu Ministriv Ukrainy "Pro skhvalennia stratehii rozvytku promyslovoho kompleksu Ukrainy na period do 2025 roku" [Ministry of economic development and trade of Ukraine. The ordinance draft "On approval the Strategy of Ukraine for the industrial complex development up to 2025"]. [onlaine] (Ostannie onovlennia 17 Kviten 2018) Dostupno: <http://www.me.gov.ua/ $\mathrm{D}$ o c u m e n t s/D e ta i l ? 1 a n g = u k - U A \& i d = 10 e f 5 b $65-0209-4$ a a 1 - a $724-$ $49 \mathrm{fd} 0877 \mathrm{~d} 8 \mathrm{~d} 6 \&$ title=ProektRozporiadzhenniaKabinetuMinistrivUkrainiproSkhvalenniaStrategii RozvitkuPromislovogoKompleksuUkrainiNaPeriodDo2025-Roku> (Data zvernennia 2 Traven 2019), [in Ukrainian].

Pryhodii, M.A., 2018. Derzhavnyi reiestratsiinyi nomer 0118U003223. Metodychni osnovy rozroblennia SMARTkompleksiv dlia pidhotovky kvalifikovanykh robitnykiv ahrarnoi, budivelnoi i mashynobudivnoi haluzei [Methodological basis of SMART-complexes for training the skilled workers of agriculture, building and car manufacturing sectors]. Laboratoriia elektronnykh navchalnykh resursiv, IPTO NAPS Ukrainy [Laboratory for digital training resources, Institute of vocational education and training of NAES of Ukraine], perehlianuto 22 Kviten 2019, [in Ukrainian].

Segodnya [Today], 2017. Top-10 novyih professiy $v$ ukrainskoy promyishlennosti [Top-10 for new job in the Ukrainian industry]. [online] (Ostannie onovlennia 29 Veresen 2017) Dostupno: $<$ https://www.segodnya.ua/economics/business/rabotav-vek-robotov-v-ukrainskoy-promyshlennosti-poyavlyayutsya-novye-professii-1059555.html $>$ (Data zvernennya 2 Traven 2019), [in Russian].

Ianenkova, I.H., 2017. Tsyfrova transformatsiia promyslovosti Ukrainy: kliuchovi aktsenty [The Digital Transformation of the Ukrainian Industry: Key Aspects]. Ekonomika ta upravlinnia natsionalnym hospodarstvom [National economy and management], 4, s. 179-184, [in Ukrainian].

Approved Event (UFI), 2018. Top ahro-profesii 2018 roku [Agro-jobs top 2018]. [online] (Ostannie onovlennia 1 Lystopad 2018) Dostupno: <http://interagro.in.ua/ru/6318-top-agro-profesij-2018-roku> (Data zvernennia 2 Traven 2019), [in Ukrainian].

DLOG MIT, 2017. The End of Moore's Law. [onlaine] Available at: <http://rodneybrooks.com/the-end-of-moores-law/> [Accessed 25 Aprile 2019], [in English]. 


\title{
Цифровізація професійної та фахової передвищої освіти України: проблеми і перспективи
}

\author{
Микола-Олег Сршов \\ аспірант кафедри педагогіки, Житомирський державний університет імені І.Я. Франка \\ https://orcid.org/0000-0002-6839-622X \\ e-mail:my.yershov@gmail.com
}

Реферат. Проблеми і перспективи цифровізації вітчизняної професійної (професійно-технічної) та фахової передвищої освіти висвітлено на основі узагальнення аналізу вітчизняних законодавчих документів, матеріалів українських і зарубіжних 3МI, наукових публікацій з питань реформування системи освіти України, статистичних матеріалів МОН України, Держстату України, Державної служби зайнятості, інтернет-ресурсів (HeadHanter, UNESCO Database, Approved Event (UFI), Eurostat Educational Statistics), сайтів закладів професійної (професійно-технічної) освіти (далі: ЗП(ПТ)О) та фахової передвищої, аналітичних матеріалів та звітів Інституту професійно-технічної освіти НАПН України, Інституту інформаційних технологій і засобів навчання НАПН України.

Виявлено й охарактеризовано загальні проблеми цифровізації вітчизняної професійної (професійно-технічної) та фахової передвищої освіти, а саме: відставання темпів розвитку освіти (зміст, форми й методи навчання, технічне оснащення) від темпів розвитку цифрових технологій; застарілість спеціальностей, за якими заклади ЗП(ПТ)О готують фахівців; неузгодженість змісту навчальних програм із потребами ринку праці; консервативні методи і форми навчання майбутніх фахівців та підвищення кваліфікації педагогів; відстала матеріально-технічна база закладів освіти; недостатній рівень цифрової компетентності багатьох керівників закладів освіти та педагогічних працівників; низький рівень комунікації між бізнесом, ІТ-компаніями та закладами освіти. Визначено перспективи цифровізації професійної (професійно-технічної) та фахової передвищої освіти в контексті розбудови цифрового суспільства та розвитку цифрової економіки: зміцнення публічно-приватного партнерства; впровадження дуальної форми навчання; запровадження інклюзивного навчання; використання в освітньому процесі компетентнісного підходу; організація дистанційного та змішаного навчання (blended learning); створення науково-освітніх on-line платформ; вибудовування у закладах освіти індивідуальних освітніх траєкторій для працевлаштування на "цифрових робочих місцях"; запровадження нових форм і методів підвищення цифрової компетентності педагогів (цифрові майстерні, баркемпи, віртуальні лабораторії).

Ключові слова: IT-освіта, цุифровізаџія (діджиталізаџія) освіти, ичифрова компетентність, ичифрова культура, професійна та фахова передвища освіта. 